\title{
Evaluation of Nile tilapia strains cultivated in cages under different feeding programmes $^{1}$
}

\section{Thiago Archangelo Freato ${ }^{2}$, Rilke Tadeu Fonseca de Freitas ${ }^{3}$, Maria Emília de Sousa Gomes Pimenta $^{4}$, Giovanni Resende de Oliveira ${ }^{2}$, Rafael Vilhena Reis Neto ${ }^{5}$, Bruno Olivetti de Mattos $^{5}$}

\footnotetext{
1 Research financed by FAPEMIG and CNPq

2 Empresa de Pesquisa Agropecuária de Minas Gerais - EPAMIG.

${ }^{3}$ Departamento de Zootecnia - UFLA. Bolsista do CNPq.

${ }^{4}$ Departamento de Ciências dos Alimentos - UFLA.

5 Pós-graduando em Zootecnia - UFLA.
}

\begin{abstract}
The objective of this study was to evaluate the performance of three Nile tilapia Oreochromis niloticus strains cultivated in cages and subjected to different feeding programmes. Initially, 31,200 Nile tilapia juveniles with an average weight of $61.15 \mathrm{~g}$ were distributed in 48 cages. Two genetically improved strains were used together with one from the Fish Culture Section of Universidade Federal de Lavras (UFLA). The fish were subjected to four feeding programmes, consisting of different levels of crude protein (CP) in diets provided at different stages of cultivation. There was no interaction effect of the strain and feeding programme for most variables. The UFLA strain presented the highest weight gain, but with greatest lack of uniformity at the end of cultivation. The feeding programme with diets containing $36 \% 32 \%$ and $28 \%$ CP, consecutively, promoted the highest weight gain and highest final biomass. The UFLA strain has great growth potential, justifying the development of a breeding programme for this strain. Crude protein levels below 36\% for tilapias between 60 and $170 \mathrm{~g}$ and below $32 \%$ for tilapias between 170 and $700 \mathrm{~g}$ worsen fish performance.
\end{abstract}

Key Words: crude protein, growth performance, nutritional requirements, Oreochromis niloticus

\section{Introduction}

The tilapia production system intensification in both Brazil and the world has required a constant search for more productive strains (Santos et al., 2007). Thus, different Nile tilapia strains with high production potential, which resulted from breeding programmes, have been marketed in Brazil.

However, according to Santos (2009), much of the Brazilian aquaculture production is still based on the use of unimproved strains, or strains improved by a mass selection process without inbred mating discrimination, damaging their growth rates. In addition, due to the presence of genotype $\times$ environment interactions, the adaptive capacity differences can influence fish performance and, consequently, the relative merit of their genotypes according to the environment in which they are being cultivated. Thus, the intensification of research evaluating these fish farmed in our environments and breeding programmes is justified, since it aims to obtain strains adapted to our environmental conditions, feed management and production systems.

According to Furuya et al. (2001), the high biomass per area and nutrient deficiencies or imbalances can result in low productivity and, hence, smaller economic return, especially in super-intensive systems.

Although the nutritional requirements of the Nile tilapia have already been determined outside Brazil and published by the National Research Council (NRC, 1993) and recently in Brazil by Furuya (2010), there are several factors that affect them, such as age or growth stage, temperature, feed used in the diet formulation, animal genetics and the production system, which can alter the responses of fish to commercial diets.

Feed is responsible for most of the production costs in farmed tilapia and the most expensive fraction is, certainly, the protein, considering the high crude protein (CP) levels in feed used to ensure good performance (Hayashi et al., 2002). Thus, studies have focused on the search for information to assist in reducing the protein content in the diet, provided at each stage of cultivation, without harm to fish productive performance (Furuya et al., 2005).

In this context, the present study was carried out to evaluate the strain and feeding programme effect on the performance of Nile tilapia Oreochromis niloticus farmed in cages. 


\section{Material and Methods}

This study was carried out at the Três Marias dam at the Experimental Farm of Empresa de Pesquisa Agropecuária de Minas Gerais (EPAMIG), located in the city of Felixlândia, in the west of Minas Gerais state, Brazil.

Initially, 31,200 male Nile tilapia Oreochromis niloticus juveniles with initial average weight of $61.15 \mathrm{~g}$ of three different strains were used: two genetically improved and usually marketed in Brazil and one from the Universidade Federal de Lavras (UFLA), Department of Aquaculture. Since the early 1970s, the UFLA strain has been randomly mating and without selection using several sources of Nile tilapia, mainly from the Bouaké strain, originally from the Ivory Coast, Africa, brought to Brazil in 1971. The fish were distributed in 48 cages, with four cubic meters of usable volume in an initial stocking density of 162.5 fish per $\mathrm{m}^{3}$.

The feeding programmes studied were classified according to their diet CP levels provided at different stages of cultivation (Table 1 ).

The feeding programmes were determined using 32\% CP as the base level, as recommended by the NRC (1993) for the cultivation of the Nile tilapia. The daily feed amount supplied was calculated according to the feed rate recommended by the manufacturer, with respect to the biomass of the cages with the same strain and under the same feeding programme, estimated at fortnight biometrics.

Ten fish from each cage were sampled monthly, until the fish reached the approximate weight of $700 \mathrm{~g}$, resulting in a final density of approximately $150 \mathrm{fish} / \mathrm{m}^{3}$, as recommended by Gontijo et al. (2008).

For the productive performance study, the sampled fish were slaughtered, weighed and measured for standard length. The performance variables analysed were: final weight, final biomass, weight gain, survival rate, cage uniformity, apparent feed conversion (AFC = feed intake/ weight gain), protein efficiency ratio (PER = weight gain/ crude protein intake) and specific growth rate. Additionally, feed and CP intake per fish, total feeding cost during the farming and feeding cost per unit of weight gain were evaluated.

The fish uniformity in each cage was estimated as proposed by Furuya et al. (1998). The equation proposed by Legendre \& Kerdchuen (1995) was used to calculate the specific growth rate (SGR).

The experimental design was completely randomized in a $3 \times 4$ factorial arrangement, with three strains of Nile tilapia (UFLA and 2 commercial strains) and four feeding programmes, with four replications.

Later, to determine the interaction of the feeding programme and the strain effect on fish body weight in each of the samples collected, the cultivation age was included as a subplot in the model.

The data were subjected to variance analysis using the computer package SAEG (Sistema de Análises Estatísticas e Genéticas, version 9.1).

\section{Results and Discussion}

During the experimental period, the minimum temperatures inside the cages were observed to range from $21.4^{\circ} \mathrm{C}$ to $25.4^{\circ} \mathrm{C}$, with an average of $23.71 \pm 1.62^{\circ} \mathrm{C}$ and the maximum ranged from $23.5^{\circ} \mathrm{C}$ to $29.0^{\circ} \mathrm{C}$, with an average of $26.63 \pm 1.98{ }^{\circ} \mathrm{C}$. The dissolved oxygen levels in water ranged from $5.61 \mathrm{mg} / \mathrm{L}$ to $7.20 \mathrm{mg} / \mathrm{L}$, with an average of $6.58 \pm 0.85 \mathrm{mg} / \mathrm{L}$, remaining always above the minimum recommended (4.0 mg/L) by Sipaúba-Tavares (1995).

An interaction effect between strain and diet programme was observed only for feed intake (FI), crude protein intake (CPI) and total cost with feeding (Table 2). Programme 1 resulted in higher FI for all strains, while programme 2 resulted in higher CPI and feeding costs for UFLA and one of the commercial strains. In contrast, programme 4 resulted in lower CPI and feeding costs for all strains. It is clear, therefore, that the cost of feeding is found to be more related to protein intake than total feed intake. The UFLA strain showed higher FI, CPI and feeding costs in almost all feed programmes, except for the feeding programme 2 .

Table 1 - Crude protein (CP) levels (\%) and grain size (mm) of different diets used in feeding programmes, according to fish weight ranges during cultivation in cages

\begin{tabular}{|c|c|c|c|c|c|}
\hline \multirow{2}{*}{\multicolumn{2}{|c|}{ Weight ranges (g) }} & \multicolumn{4}{|c|}{ Feeding programmes } \\
\hline & & $\mathrm{P} 1$ & $\mathrm{P} 2$ & P3 & $\mathrm{P} 4$ \\
\hline 60 & 110 & $32 \%$ CP (4-6 mm) & $36 \%$ CP (4-6 mm) & $36 \%$ CP (4-6 mm) & $36 \%$ CP $(4-6 \mathrm{~mm})$ \\
\hline 170 & 330 & $32 \%$ CP $(8 \mathrm{~mm})$ & $28 \%$ CP $(8 \mathrm{~mm})$ & $32 \%$ CP (8 mm) & $28 \%$ CP $(8 \mathrm{~mm})$ \\
\hline 330 & 700 & $32 \%$ CP $(8 \mathrm{~mm})$ & $28 \% \mathrm{CP}(8 \mathrm{~mm})$ & $28 \%$ CP $(8 \mathrm{~mm})$ & $22 \%$ CP (8 mm) \\
\hline
\end{tabular}

R. Bras. Zootec., v.41, n.6, p.1332-1336, 2012 
Unlike the current study, Santos (2009), studying three tilapia strains with dietary protein levels of $28 \%$ and $34 \%$, found group genetic and protein level interaction effects on fish performance, suggesting the presence of genotype $\times$ environment interaction, and concluded that the productivity optimization and improvement programmes depend on the farmed environment and the choice of fish selection environment.

The UFLA strain had the highest weight gain, but with less uniformity at the end of cultivation, probably because this strain did not undergo any selection process of production characteristics (Table 3).

The growth performance differences between strains of Nile tilapia were also highlighted by Wagner et al. (2004), who observed the superiority of the Chitralada or 'Thai'

Table 2 - Mean values of feed intake, crude protein intake and total costs of feeding during cultivation of Nile tilapia strains subjected to different feeding programmes

\begin{tabular}{|c|c|c|c|c|}
\hline \multirow[b]{2}{*}{ Strain } & \multicolumn{4}{|c|}{ Feeding programmes } \\
\hline & $\mathrm{P} 1$ & $\mathrm{P} 2$ & P 3 & P 4 \\
\hline & \multicolumn{4}{|c|}{ FI (g/fish) } \\
\hline UFLA & 1091.89Ac & $1083.55 \mathrm{Bd}$ & $1160.10 \mathrm{Aa}$ & 1141.69Ab \\
\hline COM1 & 1017.89Cd & $1056.55 \mathrm{Cb}$ & $1143.11 \mathrm{Ba}$ & $1026.58 \mathrm{Cc}$ \\
\hline \multirow[t]{2}{*}{ COM2 } & $1073.49 \mathrm{Bc}$ & $1104.31 \mathrm{Ab}$ & $1140.21 \mathrm{Ca}$ & $1060.24 \mathrm{Bd}$ \\
\hline & \multicolumn{4}{|c|}{ CPI (g/fish) } \\
\hline UFLA & 349.41Aa & $317.65 \mathrm{Bc}$ & 335.93Ab & 280.26Ad \\
\hline COM1 & $325.73 \mathrm{Cb}$ & $311.07 \mathrm{Cc}$ & $330.86 \mathrm{Ba}$ & $253.25 \mathrm{Cd}$ \\
\hline \multirow[t]{2}{*}{ COM2 } & $343.52 \mathrm{Ba}$ & 323.35Ac & $330.46 \mathrm{Bb}$ & 261.30Bd \\
\hline & \multicolumn{4}{|c|}{ COST (R\$) } \\
\hline UFLA & $1.52 \mathrm{Aa}$ & $1.43 \mathrm{Bc}$ & $1.48 \mathrm{Ab}$ & $1.36 \mathrm{Ad}$ \\
\hline COM1 & $1.41 \mathrm{Cb}$ & $1.40 \mathrm{Cc}$ & $1.46 \mathrm{Ba}$ & $1.23 \mathrm{Cd}$ \\
\hline COM2 & $1.49 \mathrm{Ba}$ & $1.45 \mathrm{Ac}$ & $1.46 \mathrm{Bb}$ & $1.47 \mathrm{Bd}$ \\
\hline
\end{tabular}

Means followed by different uppercase letters in the column and lowercase letters in the row differ $(\mathrm{P}<0.05)$ by the SNK test.

FI - feed intake per individual; CPI - crude protein intake per individual; COST feeding costs during cultivation; COM1 - commercial strain 1, COM2 - commercial strain 2 .

Table 3 - Mean values of performance and feeding costs of the production of Nile tilapia strains farmed in cages

\begin{tabular}{lcccc}
\hline Variables & \multicolumn{3}{c}{ Strain } & CV (\%) \\
\cline { 2 - 4 } & UFLA & COM1 & COM2 \\
\hline Initial weight (g) & 61.85 & 63.30 & 58.31 & 12.49 \\
Final weight (g) & $745.83 \mathrm{a}$ & $662.28 \mathrm{c}$ & $690.95 \mathrm{~b}$ & 7.83 \\
Final biomass (kg/m³) & 110.60 & 98.89 & 102.72 & 8.41 \\
Weight gain (g) & $683.98 \mathrm{a}$ & $598.98 \mathrm{c}$ & $632.64 \mathrm{~b}$ & 8.75 \\
DWG (g/day) & $5.18 \mathrm{a}$ & $4.54 \mathrm{c}$ & $4.79 \mathrm{~b}$ & 8.75 \\
Survival (\%) & 97.37 & 98.00 & 97.54 & 0.89 \\
Uniformity (\%) & $62.50 \mathrm{c}$ & $88.75 \mathrm{a}$ & $73.75 \mathrm{~b}$ & 12.77 \\
AFC & 1.65 & 1.79 & 1.74 & 8.33 \\
PER & 2.14 & 1.97 & 2.02 & 8.27 \\
SGR (\%/day) & 1.87 & 1.78 & 1.86 & 6.02 \\
COST/KG (R\$/kg) & 2.13 & 2.31 & 2.25 & 8.70 \\
\hline
\end{tabular}

Means followed by different letters in the row differ $(\mathrm{P}<0.05)$ by SNK test. CV - variation coefficient; DWG - daily weight gain; AFC - apparent feed conversion; PER - protein efficiency ratio; SGR - specific growth rate; COST/KG feeding costs per kg of fish produced; COM1 - commercial strain 1; COM2 commercial strain 2 . strain, compared with the Bouaké, and the hybrid between these two strains, which showed intermediate weight gains. The authors attributed the low performance of Bouake to the high inbreeding rate in the strain due to the introduction in Brazil of only a few individuals almost 40 years ago. Moreira et al. (2000) showed that the degree of heterozygosity of the introduced Thai population is much higher than that of the Bouaké strain; this may be an important factor explaining the growth performance of different strains.

Studying the Supreme, Bouaké and Chitralada strains, Vieira et al. (2005) observed the Supreme strain superiority, with the highest efficiency, confirming the effect of genetic improvement on the production characteristics.

Despite the greater weight gain of the UFLA strain, there were no differences in apparent feed conversion, protein efficiency ratio or cost per kilo of fish, due to higher feed and crude protein intake, and consequently, higher feeding costs. Therefore, the best performance of the UFLA strain is explained mainly by the shorter cultivation period, reducing operating costs.

In general, this means that the feeding cost per $\mathrm{kg}$ of fish produced ( $\mathrm{R} \$ 2.23 / \mathrm{kg}$ ) was relatively high, considering that approximately $50 \%$ to $70 \%$ of production costs are related to feed (Carneiro et al., 1999; Campos et al., 2007).

Based on the study of Lovshin (1997) and Gontijo et al. (2008) and considering the period of 142 days with an initial weight of $61.15 \mathrm{~g}$, the performance values observed were satisfactory.

With the exception of the apparent feed conversion and protein efficiency ratio, all other performance characteristics were affected by the feeding programmes (Table 4).

Unlike the current study, Furuya et al. (2005), studying the digestible protein levels in the diet $(25.5 \%, 27.0 \%$, $28.5 \%, 30.0 \%$ ) for Nile tilapia, found that higher levels resulted in a linear reduction in the protein efficiency ratio and, consequently, a linear increase in nitrogen excretion, but no influence on weight gain.

The feeding programme 3 showed the best results in weight gain, regardless of strain. The absolute weight gain was more related to the total FI and, probably, to the supply of the appropriate protein level for each cultivation stage, than the total crude protein intake, which was higher in feeding programme 1 .

There was no significant difference between specific growth rates in programmes 1 and 3, indicating that, proportionally with initial weight, they showed similar growth. Both programmes showed an increase in weight gain compared with the other treatments, but with a higher total feeding cost, not influencing the feeding cost per $\mathrm{kg}$ of fish produced. 
Table 4 - Mean values of performance and feeding costs of production of Nile tilapia subjected to different feeding programmes

\begin{tabular}{|c|c|c|c|c|c|}
\hline \multirow[b]{2}{*}{ Variables } & \multicolumn{4}{|c|}{ Feeding programmes } & \multirow[b]{2}{*}{ CV (\%) } \\
\hline & $\mathrm{P} 1$ & $\mathrm{P} 2$ & P 3 & $\mathrm{P} 4$ & \\
\hline Initial weight (g) & 55.13 & 63.98 & 60.32 & 65.18 & 12.49 \\
\hline Final biomass $\left(\mathrm{kg} / \mathrm{m}^{3}\right)$ & $107.71 \mathrm{~b}$ & $102.79 b$ & $111.40 \mathrm{a}$ & $94.39 c$ & 8.41 \\
\hline Weight gain (g) & $663.48 b$ & $631.05 b$ & $681.02 \mathrm{a}$ & $578.57 c$ & 8.75 \\
\hline DWG (g/day) & $5.03 \mathrm{~b}$ & $4.78 b$ & $5.16 \mathrm{a}$ & $4.38 c$ & 8.75 \\
\hline AFC & 1.61 & 1.72 & 1.70 & 1.87 & 8.33 \\
\hline PER & 1.95 & 1.99 & 2.05 & 2.18 & 8.27 \\
\hline SGR (\%/day) & $1.93 a$ & $1.80 \mathrm{~b}$ & $1.89 \mathrm{ab}$ & $1.73 c$ & 6.02 \\
\hline COST/KG (R $\$ / k g)$ & 2.24 & 2.26 & 2.18 & 2.24 & 8.70 \\
\hline
\end{tabular}

Means followed by different letters in the row differ $(\mathrm{P}<0.05)$ by the SNK test.

CV - variation coefficient; DWG - daily weight gain; AFC - apparent feed conversion; PER - protein efficiency ratio; SGR - specific growth rate; COST/KG - feeding cost per kg of fish produced.

In general, this means that feeding programme 4 showed the worst performance results, probably due to the low level of protein (22\% CP) provided for a long period at the finishing stage, indicating that this protein level is below the nutritional requirements of the species.

In the fish body weight analysis, considering the different cultivation ages, there was no interaction effect between cultivation age and strain. However, an interaction effect between cultivation age and feeding programme was observed, so in each cultivation age, the fish showed different responses to feeding programmes, regardless of the cultivated strain (Figure 1).

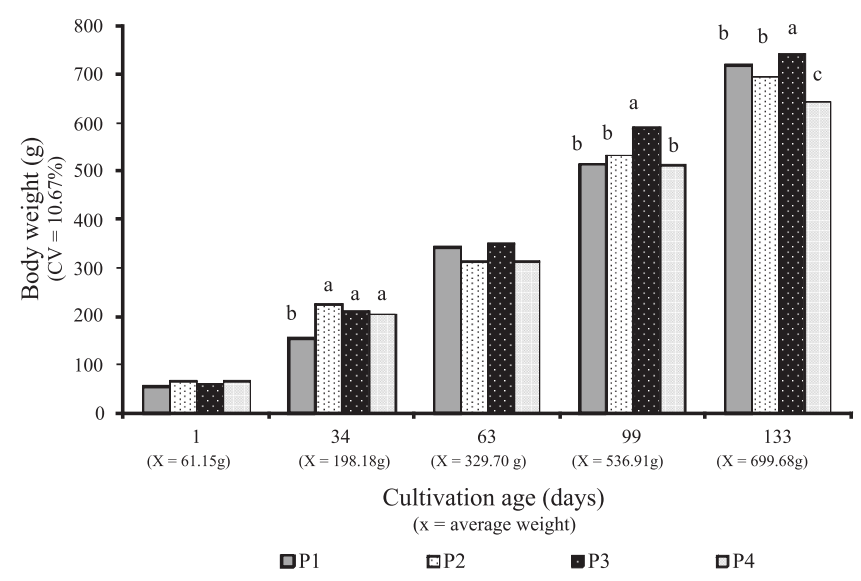

Means followed by different letters on the columns differ $(\mathrm{P}<0.05)$ by SNK test. P1 - 32\% CP throughout the cultivation period; P2 - 36\% of CP in the first phase and 28\% CP in the second phase; P3 - 36\%, 32\% and 28\% CP in the first, second and third phases, respectively; P4 - 36\%, 28\% and 22\% CP in the first, second and third phases, respectively.

Figure 1 - Body weight of Nile tilapia subjected to different feeding programmes in consecutive samples taken during the experimental period.
Between the 1st and 34th days of cultivation, feeding programmes 2, 3 and 4 resulted in a greater increase in body weight, probably because this was the period in which these programmes provided diets with $36 \%$ crude protein, higher than programme 1, with $32 \% \mathrm{CP}$. This suggests that CP levels below $36 \%$ worsened the performance of fish between 60 and $170 \mathrm{~g}$.

For fish between approximately 170 and 330 g, programmes 1 and 3, which provided diets with $32 \% \mathrm{CP}$, resulted in greater weight increase than the treatments that provided diets with 28\% CP.

Programme 3 showed the best weight results for fish from the 63rd cultivation day, with a supply of $28 \% \mathrm{CP}$ for 330 to $700 \mathrm{~g}$ fish. Nevertheless, in the last 34 days of cultivation, there was a weight increase of $40 \%$ in the fish in programme 1 , while in treatment 3 , this increase was $25 \%$. This result indicates that even in the final cultivation stages, CP levels below 32\% may damage the performance of tilapia in cages.

Similarly, Costa et al. (2009), studying CP levels for the tilapia Chitralada strain in cages, observed that fish fed 36\% $\mathrm{CP}$ in the growth phase from 80 to $300 \mathrm{~g}$ performed better in the later stage (310-650 g) than those fed 32\% CP. These authors suggest a minimum level of 32\% CP to grow fish weighing more than 80 grams in cages.

Unlike in the present study, Fulber et al. (2010), evaluating different tilapia strains reared in ponds in the weight range from 41.6 to $363.7 \mathrm{~g}$, observed that the diets with $25 \%$ CP levels resulted in weight gain greater than the tilapia fed $30 \%$ CP, indicating less need for CP at this stage of growth and the need for greater attention to the biological value of the ingredients in feed formulations for this species. However, in the pond cultivation system, the influence of natural feeds can be more effective than in the cage cultivation system. 


\section{Conclusions}

From diets with adequate crude protein levels for each phase, it is possible to reduce the crude protein intake during growth and, consequently, the feeding cost, with no damage to fish performance. However, diets with levels below 36\% CP for fish weighing between 60 and $170 \mathrm{~g}$ and below $32 \% \mathrm{CP}$ for fish weighing between 170 and $700 \mathrm{~g}$ can damage the performance of this species in cages, regardless of the strain reared.

\section{References}

CAMPOS, C.M.; GANECO, L.N.; CASTELLANI, D. et al. Avaliação econômica da criação de tilápias em tanque-rede, município de Zacarias, SP. Boletim do Instituto de Pesca, v.33, n.2, p.265-271, 2007.

CARNEIRO, P.C.; MARTINS, M.I.E.G.; CYRINO, J.E.P. Estudo de caso da criação comercial da tilápia vermelha em tanques-rede: Avaliação econômica. Informações Econômicas, v.29, n.8, p.52-61, 1999.

COSTA, M.L.S.; MELO, F.P.; CORREIA, E.S. Efeitos de diferentes níveis protéicos da ração no crescimento na tilápia do Nilo (Oreochromis niloticus Linnaeus, 1757), variedade chitralada, criadas em tanques-rede. Boletim do Instituto de Pesca, v.35, n.2, p.285-294, 2009.

FÜLBER, V.M.; RIBEIRO, R.P.; VARGAS, L.D. et al. Desempenho produtivo de três linhagens de tilápia-do-nilo (Oreochromis niloticus) alimentadas com dois níveis de proteína. Acta Scientiarum: Animal Sciences, v.32, n.1, p.77-83, 2010.

FURUYA, W.M. Tabelas brasileiras para a nutrição de tilápias. Toledo: GFM, 2010. 100p.

FURUYA, W.M.; BOTARO, D.; MACEDO, R.M.G. et al. Aplicação do conceito de proteína ideal para redução dos níveis de proteína em dietas para Tilápia do Nilo (Oreochromis niloticus). Revista Brasileira de Zootecnia, v.34, n.5, p.1433-1441, 2005.

FURUYA, W.M.; PEZZATO, L.E.; PEZZATO, A.C. et al. Coeficientes de digestibilidade e valores de aminoácidos digestíveis de alguns ingredientes para tilápia do Nilo (Oreochromis niloticus). Revista Brasileira de Zootecnia, v.30, n.4, p.1143-1149, 2001.
FURUYA, W.M.; SOUZA, S.R.; FURUYA, V.R.B. et al. Dietas peletizada e extrusada para machos revertidos de tilápias do Nilo (Oreochromis niloticus L.) na fase de terminação. Ciência Rural, v.28, n.3, p.483-487, 1998.

GONTIJO, V.P.; CARDOSO, E.L.; OLIVEIRA, G.R. et al. Cultivo de tilápia em tanques-rede. Lavras: EPAMIG, 2008. 44p. (Boletim Técnico, 89).

HAYASHI, C.; BOSCOLO, W.R.; SOARES, C.M. et al. Exigência de proteína digestível para larvas de Tilápia do Nilo (Oreochromis niloticus, L.), durante a reversão sexual. Revista Brasileira de Zootecnia, v.31, n.2, p.823-828, 2002 (supl.) LEGENDRE, M.; KERDCHUEN, N. Larval rearing of an African Catfish (Heterobranchus longifilis Teleostei, Claridae): effect of dietary lipids on growth survival and fatty acid composition of fry. Aquatic Living Resources, v.8, n.4, p.355-363, 1995.

LOVSHIN, L.L. Tilapia farming: a growing worldwide aquaculture industry. In: SIMPÓSIO SOBRE MANEJO E NUTRIÇÃO DE PEIXES, 1997, Piracicaba. Anais... Piracicaba: Colégio Brasileiro de Nutrição Animal, 1997. p.137-164.

MOREIRA, H.L.M.; DELLAGOSTIN, O.A.; ERDTMANN, B. Levels of inbreeding and relatedness in breeder stocks of Nile Tilapia (Oreochromis niloticus) detected by microsatellite analysis. In: INTERNATIONAL SYMPOSIUM ON TILAPIA IN AQUACUlture, 5., 2000, Rio de Janeiro. Anais... Rio de Janeiro: ISTA, 2000. p.59-67.

NATIONAL RESEARCH COUNCIL - NRC. Nutrient requirements of warmwater, fishes and shellfishes: nutrient requirements of domestics animals. Washington, D.C.: 1993. 114p.

SANTOS A.I. Interação genótipo - ambiente e estimativas de parâmetros genéticos em tilápias. 2009. 82f. Tese (Doutorado em Zootecnia) - Universidade Estadual de Maringá, Maringá.

SANTOS, V.B.; FREITAS, R.T.F.; LOGATO, P.V.R. et al. Rendimento do processamento de linhagens de tilápias (Oreochromis niloticus) em função do peso corporal. Ciência e Agrotecnologia, v.31, n.2, p.554-562, 2007.

SIPAÚBA-TAVARES, L.H. Limnologia aplicada à aqüicultura Jaboticabal: FUNEP, 1995. 70p.

VIEIRA, V.P. RIBEIRO, R.P.; MOREIRA, H.L.M. et al. Avaliação do desempenho produtivo de linhagens de tilápia do Nilo (Oreochromis niloticus) em Maringá-PR. Revista Acadêmica, v.3, n.3, p.19-26, 2005.

WAGNER, P.M.; RIBEIRO, R.P.; MOREIRA, H.L.M. et al. Avaliação do desempenho produtivo de linhagens de Tilápia do Nilo (Oreochromis niloticus) em diferentes fases de criação. Acta Scientiarum: Animal Sciences, v.26, n.2, p.187-196, 2004 